\title{
GCU
}

Glasgow Caledonian

University

University for the Common Good

\section{An analysis of involuntary excess reserves, monetary policy and risk-taking behaviour of Chinese banks}

Nguyen, Vu Hong Thai; Boateng, Agyenim

Published in:

International Review of Financial Analysis

DOI:

10.1016/j.irfa.2014.11.013

Publication date:

2015

Document Version

Early version, also known as pre-print

Link to publication in ResearchOnline

Citation for published version (Harvard):

Nguyen, VHT \& Boateng, A 2015, 'An analysis of involuntary excess reserves, monetary policy and risk-taking behaviour of Chinese banks', International Review of Financial Analysis, vol. 37, pp. 63-72.

https://doi.org/10.1016/j.irfa.2014.11.013

\section{General rights}

Copyright and moral rights for the publications made accessible in the public portal are retained by the authors and/or other copyright owners and it is a condition of accessing publications that users recognise and abide by the legal requirements associated with these rights.

Take down policy

If you believe that this document breaches copyright please view our takedown policy at https://edshare.gcu.ac.uk/id/eprint/5179 for details of how to contact us. 


\title{
An Analysis of Involuntary Excess Reserves, Monetary Policy and Risk-taking Behaviour of Chinese Banks
}

\author{
By \\ Vu Hong Thai Nguyen* and Agyenim Boateng** \\ *Eastern International University, Binh Duong, Vietnam \\ **Glasgow Caledonian University, Glasgow, UK
}

\begin{abstract}
In this paper, we examine the effects of monetary policy on the risk-taking behaviour of Chinese banks in the presence of involuntary excess reserves based on a sample of 95 banks. We find that involuntary excess reserves appear to lead to more aggressive risk-taking in the Chinese banking market. This implies that the large involuntary excess reserves stimulate the rapid expansion of credit and the price bubble in the Chinese financial market. However, banks with larger involuntary excess reserves tend to reduce risk-taking more rapidly under the tightening monetary policy regime. The sheds lights on the effectiveness of government monetary policy in reducing the risk-taking behaviour of banks in an emerging market where involuntary excess reserves are present.
\end{abstract}




\section{$1 \quad$ Introduction}

Easy monetary conditions are a classic ingredient of financial crisis (Borio and Zhu, 2008; Gambacorta, 2009). It is therefore not surprising that, recent studies have examined how monetary policy may contribute to an excessive expansion of credit and consequently banks' risk-taking behaviour. Expansionary monetary policy strengthens banks' net-worth, induces banks to increase leverage by expanding assets aggressively and banks' risk-taking, pointing to a different dimension of the monetary transmission mechanism, the so-called risk-taking channel (Borio and Zhu, 2008; Adrian and Shin, 2009; Adrian and Shin, 2010). Conversely, the extant literature on risk-taking channel largely supports the contention that tightening monetary policy tends to reduce banks' risk-taking incentive (Jimenez et al., 2009; Ioannidou et al., 2009; Altunbas et al., 2010; Delis and Kouretas, 2011; Maddaloni and Peydró, 2011). It is pertinent to note that while these studies have been in the context of both advanced market and emerging economies, the results have been mixed (see Delis and Brissimis, 2010; Delis and Kouretas, 2011; Maddaloni and Peydró, 2011; Michalak, 2012; De Graeve et al., 2008; Buch et al., 2011). Moreover, prior studies have virtually not examined the topic in an emerging market economy such as China where the presence of large involuntary excess reserves ${ }^{1}$ in the banking system is large. The aggregate excess reserves beyond statutory requirements in Chinese banking system stood at an average of $10 \%$ of deposit base in the 1990s and the early 2000s (Anderson, 2009; Laurens and Maino, 2009), although the ratio gradually fell to $3.3 \%$ in $2012^{2}$, yet it is judged to be high compared to banks in the US and Euro-zone countries and higher than precautionary level (Wei et al., 2008; Anderson, 2009; Ma et al., 2011). The large involuntary excess reserves in the Chinese banking system have raised some concerns regarding the forming of price bubble which may result in financial

\footnotetext{
${ }^{1}$ Involuntary excess reserves is defined as unwanted reserve above the precautionary excess reserves level (Agenor et al., 2004)

${ }^{2}$ Source: China Monetary Policy Reports, retrieved from the website of The People's Bank of China
} 
crisis (Zhang and Pang, 2008; Zhang, 2009; Yang, 2010; Huang et al., 2010; Guo and Li, 2011). The presence of involuntary excess reserves indicates unwanted surplus liquidity (Agenor et al., 2004). It is argued that the low probability of illiquidity risk induces bank managers to relax credit lending standards and lend out more aggressively to increase managerial compensation which is often tied to credit volume and exacerbate agency problem (Acharya and Naqvi, 2012). While bank managers may be remunerated inversely to the risk they take, Acharya and Naqvi (2012) argue that the surplus liquidity environment makes the risk-taking behaviour easier to conceal. Yet, we know very little regarding the effectiveness of tightening monetary policy on risk-taking behaviour in a situation such as China where large involuntary excess reserves is present in the banking system. To fill this gap, we investigate the linkage between involuntary excess reserves, monetary policy and risk-taking bahaviour of banks in China.

In this paper, we examine the impact of monetary policy on the risk-taking behaviour of Chinese banks in the presence of involuntary excess reserves. The paper contributes to literature in two important ways: First, we clarify the impact of involuntary excess reserves on risk-taking behaviour of banks in an emerging market economy which has become more interconnected with the world economy and likely to play a more crucial role in future global financial crisis. Second, the study sheds lights on the effectiveness of government monetary policy in reducing the risk-taking behaviour of banks in the context where involuntary excess reserves are present. The study therefore extends the risk-taking channel theory in the context where large involuntary excess reserves are present in the banking market. We find that involuntary excess reserves appear to lead to more aggressive risk-taking in the Chinese banking market. This implies that the large involuntary excess reserves may stimulate the rapid expansion of credit and the price bubble in the Chinese financial market. However, banks with larger involuntary excess reserves tend to reduce risk-taking more rapidly under the tightening monetary policy regime. The results provide support to Acharya and Naqvi's 
(2012) argument that the central bank should follow a 'leaning against liquidity' approach, i.e. the central bank should adopt tightening monetary policy at times when banks are awash with liquidity to hold back banks' risk-taking incentive.

The remainder of the paper is organised as follows. Section 2 reviews the literature on the risk-taking channel and develops the hypotheses of the study. Section 3 presents data used and methodology. Section 4 discusses the estimated results with additional analysis and robustness tests. Section 5 presents study summary and conclusions of the study.

\section{Literature Review and Hypothesis Development}

Prior literature suggests that monetary policy has mixed effects on bank risk-taking. While banks' risk-taking is found to increase if the central bank reduces policy interest rates or keeps interest rate too low for too long (Gambacorta, 2009; De Nicolò et al., 2010; Gaggl and Valderrama, 2010; Angeloni et al., 2010; Delis and Brissimis, 2010; Delis and Kouretas, 2011; Maddaloni and Peydró, 2011; Michalak, 2012), other studies suggest that risk-taking decreases in response to the fall of monetary policy rates (De Graeve et al., 2008; Buch et al., 2011). Nguyen and Boateng (2013) find that, in the presence of involuntary excess reserves, liquid banks and large banks tend to take greater risks, and hence, they become more vulnerable to monetary policy shocks in China. The following section discusses the hypotheses in respect of monetary policy, involuntary excess reserves and risk-taking behavior of Chinese banks which to the best of our knowledge no study has attempted to examine.

\subsection{Involuntary Excess Reserves and Risk-taking}

Agenor et al. (2004) point out that, banks may voluntarily hold reserves above the statutory level (precautionary excess reserves) to buffer liquidity need. The involuntary excess reserves above the precautionary level deemed to be unwanted liquidity may stimulate aggressive lending Agenor et al., 2004; Nguyen and Boateng, 2013). This argument is consistent with 
the risk-taking theory which indicates that the surplus liquidity in the banking system leads to a perception of low probability of illiquidity risk among bank managers and consequently induces bank managers to take in more tail risk (Acharya and Naqvi, 2012). However, tail risk is the kind of risk that can be easily concealed and generates severe adverse consequences; but offers generous compensation the rest of the time (Rajan, 2006). Low illiquidity risk makes the tail risk more easily to conceal, and therefore, the bank managers tend to take greater tail risk, relax lending standards and charge lending interest rate below the fundamental level to facilitate aggressively lending and increase remuneration which is often tied to credit volume (Acharya and Naqvi, 2012). In China, the banking organisation structure reforms in 1994 changed the managers' remuneration incentives from credit-plan adherence to loan revenue and credit default rate basis (Naughton, 1998; Allen et al., 2011), and further reforms in 2002-2003 delegated lending decisions to loan managers and empowered them to set interest rates (Qian et al., 2011). The presence of involuntary excess reserves together with the volume-based remuneration is argued to induce risk-taking behaviour among Chinese bank managers. This argument leads to the first hypothesis that risk-taking has a positive relationship with involuntary excess reserves in the Chinese banking market.

H1: The risk-taking of Chinese banks has a positive relationship with involuntary excess reserves.

\subsection{Monetary Policy, Involuntary Excess Reserves and Risk-taking}

The expansionary monetary policy strengthens net-worth of banks (Bernanke et al., 1999). Under the risk-taking channel of monetary policy transmission, the strengthened net-worth improves banks' risk measurement, encourages banks to increase leverage and expand credit to borrowers whose risk measurement is also improved but business risk fundamentals remain unchanged, thus, banks' risk-taking tends to increase (Borio and Zhu, 2008; Adrian and Shin, 2009; Adrian and Shin, 2010). Expansionary policy may also make banks search 
for yield (Rajan, 2006) or signal the central banks' policy stance on liquidity support if the market liquidity situation gets worse (Gambacorta, 2009; Altunbas et al., 2010), and therefore, banks are induced to take greater risk. Drawing on this reasoning, tightening monetary policy is argued to weaken banks' net-worth, which in turn reduces risk-taking. Prior studies suggest that Taylor-Gap can better capture the monetary policy stance (Altunbas et al., 2010; Gaggl and Valderrama, 2010; Maddaloni and Peydró, 2011 and Michalak, 2012). Taylor-Gap is the difference between the actual monetary policy interest rate and the rate implied by Taylor rule (Taylor, 1993). According to Taylor's rule (Taylor, 1993), monetary policy should pursue both short-term goal of stabilising the economy and long-term goal of moderating inflation. Taylor-Gap is measured as the residuals of Taylor-rule estimations where the monetary policy interest rates are regressed on gross domestic product (GDP) growth and inflation. Prior studies point out that the positive Taylor-Gap indicates the tightening monetary policy because the central bank sets the policy interest rate higher than the recommended rate based on Taylor rule (Altunbas et al., 2010; Gaggl and Valderrama, 2010; Maddaloni and Peydró, 2011 and Michalak, 2012). The higher the Taylor-Gap, the more strongly the monetary policy is tightened. Similarly, the negative Taylor-Gap indicates the expansionary monetary policy. As tightening monetary policy is argued to discourage risk-taking, it is hypothesised that risk-taking has a negative relationship with Taylor-Gap.

H2: The risk-taking of Chinese banks has a negative relationship with Taylor-Gap.

Because expansionary monetary policy encourages risk-taking and involuntary excess reserves also induce risk-taking, it is further argued that banks with larger involuntary excess reserves take greater risk during the expansionary monetary policy regime. When the monetary policy is tightened, the net-worth of banks is adversely affected (Bernanke et al., 1999; Angeloni and Faia, 2009), the tail risk is materialised and becomes less likely to be concealed (Rajan, 2006); and therefore, the risk-taking incentive of involuntary excess reserve is argued to be reduced. Because banks with larger involuntary excess reserves are 
argued to take greater tail risk during the expansionary monetary policy regime, their tail risk is materialised more rapidly and their net-worth which is more adversely affected during the tightening monetary policy regime. From the above argument, we can conjecture that, banks with larger involuntary excess reserves reduce risk-taking more rapidly in response to the tightening monetary policy. It is therefore hypothesised that bank risk-taking has a negative relationship the interaction between involuntary excess reserves and Taylor-Gap.

H3: The risk-taking of Chinese banks has a negative relationship with the interaction between involuntary excess reserves and Taylor-Gap.

\section{$3 \quad$ Data and Methodology}

\subsection{Data}

We use the dataset compiled by Fitch's International Bank Database, Bankscope. The sample covers the period from 2000 to 2011, and includes only banks whose data are available for at least three consecutive years. Only commercial banks are selected (state-owned commercial banks, joint-stock commercial banks, city commercial banks, rural commercial banks and foreign banks); thus, policy banks, cooperative banks and investment banks are not included in our sample because they may have different objectives than profitability. The final panel sample consists of 95 banks and 552 annual observations. Macro data (including national and provincial real gross domestic product (GDP) growth rate, inflation rate and Chinese monetary policy) are collected from China Securities Market and Accounting Research database (CSMAR), the World Bank online database, China Statistical Yearbook (National Bureau of Statistics of China), and the People Bank of China website. To ensure sufficient time-series data for Taylor-Gap estimations, macro data were collected for a longer period i.e., from 1994 to 2011 inclusively and 18 annual observations. 


\subsection{Involuntary Excess Reserve Ratio (IERR) Measure}

We adopt Agenor's et al. (2004) framework and subsequently used by Nguyen and Boateng (2013) to decompose involuntary excess reserves from precautionary excess reserves. Agenor et al. (2004) developed a framework on the demand for precautionary excess reserves which is considered to be negative to requirement ratio but positive to both liquidity shock volatility and penalty rate on shortage of required reserves. We estimate demand for precautionary excess reserves and the estimation results are used to measure the involuntary excess reserves as the difference between actual excess reserves and the estimated precautionary excess reserves. Following Bindseil et al. (2006) we define excess reserves as the current account holdings of banks with the central bank beyond required reserves. Aikaeli (2011) argues that banks also tend to demand more excess reserves to buffer credit risk. To take this effect into account, we also incorporate credit risk as a determinant of precautionary excess reserves into Agenor's et al. (2004) framework. Following Agenor et al. (2004), Aikaeli (2011) and Nguyen and Boateng (2013), we model the demand for precautionary excess reserves and the estimation residual is collected as the involuntary excess reserves ratio.

$E R_{i t}=\tau+\alpha_{1} E R_{i, t-1}+\alpha_{2}(L) L R+\alpha_{3}(L) C A S H+\alpha_{4}(L) Y R+\alpha_{5}(L) R R R+\alpha_{6}(L) R+\alpha_{7} Y E A R_{t}+\varepsilon_{i t}$

where $\tau$ is a constant term, $\varepsilon_{i t}$ is a well-behaved error term and $\alpha_{j}(L)$ are lag polynomials, defined as:

$\alpha_{j}=1+\alpha_{j 1} L+\ldots+\alpha_{j p} L^{p}, j \geq 2$

$L R, C A S H$ and $Y R$ are defined by the following respective formulae:

$$
\begin{aligned}
& L R=\mid \frac{I I L}{D}-\text { Trend }\left(\frac{I I L}{D}\right) \mid \\
& \text { CASH }=\frac{V}{D}-\text { Trend }\left(\frac{V}{D}\right)
\end{aligned}
$$


$Y R=\frac{R_{G D P}}{\operatorname{Trend}\left(R_{G D P}\right)}$

Where: $I I L, D, V$ and $R_{G D P}$ are interest income on loan, total customer deposit, vault cash and real GDP growth rate, respectively. Trend is Hodrick-Prescott/Baxter-King filters.

$E R$ is a ratio of excess reserves to deposits. $E R$ is measured as the ratio of the difference between a bank's current account balance with the central bank and required reserve ${ }^{3}$ over total customer deposit. Following Aikaeli (2011) and Nguyen and Boateng (2013), loan return volatility $(L R)$ is used to capture credit risk that may trigger deposit withdrawals, $L R$ is measured as the absolute value of the deviation of loan interest income from its trend identified by the filter method developed by Hodrick and Prescott (1997). Loan interest income is the ratio of interest income on loan to total customer deposit. Hodrick-Prescott filter (HP) is a standard method for removing trend movements in the business cycle literature (Ravn and Uhlig, 2002). As loan return volatility implies a bank's easy gain or loss, credit risk arises from both negative and positive deviations (Aikaeli, 2011), hence, the absolute value of the deviation is taken into consideration.

$C A S H$ reflects cash-holding preference of depositors, measure by the volatility of the ratio of vault cash to total customer deposit by Hodrick-Prescott filter. $Y R$ is the ratio of real GDP growth rate to its trend (Hodrick-Prescott filter), capturing demand for cash. We also employ the filter developed by Baxter and King (1999) as an alternative method of measuring deviation. Moreover, $R R R$ and $R$ are the average reserve requirement ratio set by the People's Bank of China (PBC) within a certain year and the refinance interest rate, respectively; the latter term is the rate that the PBC charges when lending to financial institutions for short-

\footnotetext{
${ }^{3}$ Required reserve is measured as the product of total customer deposit and reserve requirement ratio domestic currency deposit. Since reserve requirement ratio for foreign currency deposit is smaller than that for Renminbi (RMB) deposit, the total estimated reserve requirement is slightly higher than the actual value. However, the comparison with the actual value (where available) shows that the two values are very close because foreign currency deposit accounts for a very small fraction of total customer deposit.
} 
term liquidity support (20-day call loan rate) and reflects the penalty cost if a bank falls short of the required amount of reserves. The model is estimated by System Generalised Method of Moments (SGMM) developed by Arellano and Bond (1991), Arellano and Bover (1995); Blundell and Bond (1998). The optimal SGMM model is selected based on the criteria suggested by Arellano and Bond (1991) and Roodman (2006) in Appendix 1. The number of lags is based on Aikaike Information Criteria (AIC). The error term $\varepsilon_{i t}$ which is free of unit root and serial correlation is collected to index involuntary excess reserve ratio. We denote IERR 1 and IERR2 as involuntary excess reserve ratios obtained from the residuals of precautionary excess reserves estimations with Hodrick-Prescott filter and Baxter King filter methods, respectively. The estimations results show a significantly positive relationship between credit risk and the demand for precautionary excess reserves (results provided upon request).

\subsection{Monetary Policy Stance Index}

Prior studies point out that the relationship between monetary policy and risk-taking may be endogenous because central banks tend to adjust monetary policy rate based on the observed risk-taking behaviour of commercial banks (Maddaloni and Peydró, 2011). We overcome this issue by two ways. First, we employ Generalised Method of Moments method (GMM) which provides efficient estimation with endogeneity problem (Arellano and Bond, 1991). Second, Altunbas et al. (2010), Gaggl and Valderrama (2010), Maddaloni and Peydró (2011) and Michalak (2012) argue that the use of Taylor-Gap can make the endogeneity problem between monetary policy and risk taking less significant, we use Taylor-Gap to index the monetary policy stance. The Taylor-Gap is obtained from the residual of the Taylor-rule estimation.

The Taylor rule rate is algebraically expressed as below:

$$
r_{t}^{*}=a_{c}^{*}+a_{\pi}^{*}\left[E\left(\pi_{t+1} \mid I_{t}\right)-\pi^{*}\right]+a_{y} y_{t}
$$


In which $r_{t}^{*}, \pi^{*}, y_{t}$ are target interest rate, target inflation rate and output gap (the difference between the actual GDP growth rate and the target GDP growth rate) respectively. Moreover, $\pi_{t+1}$ is the realised annual inflation rate at time $t$, the parameter $a_{c}^{*}$ is the long-run equilibrium nominal interest rate. $I_{t}$ is the information set available at time $t$. Since the inflation rate is highly persistent, $E\left(\pi_{t+1} \mid I_{t}\right)=\pi_{t}$ is adopted by Taylor and many other authors (Fan et al., 2011). Following Fan et al. (2011), we assume that $E\left(\pi_{t+1} \mid I_{t}\right)=\psi \pi_{t}$ and by denoting $a_{\pi}=\psi a_{\pi}^{*}$ and $a_{c}=a_{c}^{*}-a_{\pi}^{*} \pi^{*}$ the original Taylor equation above can be presented as:

$r_{t}^{*}=a_{c}+a_{\pi} \pi_{t}+a_{y} y_{t}$

As argued by Fan et al. (2011) that in practice the central bank tends to smooth the actual interest rate and hence, it is widely accepted in the literature that the actual interest rate $r_{t}$ is the weighted average of the target rate $r_{t}^{*}$ and its lag $r_{t-1}$, plus the noise term $\varepsilon_{t}$.

$r_{t}=(1-\rho) r_{t}^{*}+\rho r_{t-1}+\varepsilon_{t} ;$ where $0 \leq \rho<1$

or equivalently:

$r_{t}=(1-\rho)\left(a_{c}+a_{\pi} \pi_{t}+a_{y} y_{t}\right)+\rho r_{t-1}+\varepsilon_{t}$

Regarding the policy interest rate in China, it is argued that Open Market Operation rate (OMO), which is the rate that PBC uses to sell or buy government bonds in the open market, does not necessarily signal monetary policy stance but is simply a sterilisation tool (Liu et al., 2009; Chen et al., 2011). Similarly, reserve requirement increases do not necessarily reflect tightening monetary policy but serve to tame excess liquidity in the Chinese banking system (Anderson, 2009). In addition, Green and Chang (2006) find no relationship between money base M2 and reserve money in China, and argue that the PBC fails to manage M2 growth as an intermediary monetary goal. Therefore, the reserve requirement ratio and the money base 
M2 cannot represent the Chinese monetary policy stance. In contrast, policy interest benchmark rates play very influential roles in expressing PBC's monetary policy stance and have strong effects on market rates (He and Wang, 2012). However, Anderson (2009) and Porter and $\mathrm{Xu}$ (2009) point out that the policy deposit ceiling rates are strictly binding and signal the market-clearing equilibrium in China, but the lending benchmark rate is not binding in practice. Therefore, we use one-year deposit benchmark rate $(D B)$ to capture the monetary policy interest rate $\left(r_{t}\right)$ in China. Although lending benchmark rate is not binding in practice, it may still signal the monetary policy stance from the PBC. To take the effect of lending benchmark into account, we follow Fan et al. (2011) and use the average rate of lending and deposit benchmarks ( $L D B$ ) as an alternative measure of monetary policy interest rate.

With respect to the inflation and real GDP growth rates, $\pi_{t}$ is the annual inflation rate in China and $y_{t}$ is measured as the deviation of GDP annual growth rate from its trend. The deviation is captured by Hodrick and Prescott's (1997) filter. To compensate for the end-ofsample problem in the case of the Hodrick-Prescott Filter, the forecast of 2012 real GDP is employed. In May 2012, World Bank forecasted that China's 2012 GDP growth rate would be $8.2 \%$ (Zhao, 2012). Deposit benchmark rate $(D B)$ spans between $2 \%$ and $11 \%$ with the mean of $3.6 \%$. The average of deposit and lending benchmark ( $L D B$ ) varies between $3.6 \%$ and $11.255 \%$. The unit root results based on Dickey-Fuller and Phillips-Perron tests indicate that all variables are stationary. Therefore, the model can be estimated at variable level rather than first difference.

Following Fan et al. (2011), the model is estimated using non-linear least squares (NLS) which is best applied to the model with unknown parameter i.e. $\rho$. The residual term $\varepsilon$ implies the Taylor-Gap which is the difference between the actual interest rate and the target rate under Taylor rule. A positive residual term reflects a tightening monetary policy while 
the negative one indicates an expansionary monetary policy. We denote Taylor 1 and Taylor 2 as the Taylor-Gaps (i.e. residual terms) obtained from the estimations with deposit benchmark rate $(D B)$ and with the average of lending and deposit benchmark rates $(L D B)$, respectively. Taylor 1 and Taylor 2 are free of unit root and serial correlation. The estimations results indicate that the $\mathrm{PBC}$ tends to increase the deposit benchmark rate $(D B)$ and the average of lending and deposit benchmark rate $(L D B)$ in response to the increase in inflation rate and the output gap. (results provided upon request). This supports the evidence documented by Fan et al. (2011).

\subsection{Definitions of Variables}

To measure risk-taking, we use z-score developed by Boyd et al. (1993). z-score has been widely used in the risk-taking literature such as Berger et al. (2009), De Nicolò et al. (2010), Tabak et al. (2010), Gaggl and Valderrama (2010), Michalak (2012). Tabak et al. (2010) and Delis et al. (2011) point out that $z$-score is a proper proxy for risk-taking because it is able to measure the distance from insolvency of banks. $Z$-score combines profitability, leverage, and return volatility in a single measure (Berger et al., 2009). It is argued that risk taking and credit risk do not refer to the same issue, and that $\mathrm{z}$-score captures the risk taking incentive (i.e. overall risk) rather than credit risk because banks can offset the increase in credit risk by holding more capital (to reduce leverage) which in fact reduces their overall risk (Berger et al., 2009). Algebraically, z-score represents the probability of insolvency by reflecting the number of standard deviations that a bank's rate of return of assets has to fall for the bank to become insolvent.

$z-$ score $=\frac{R O A+E A}{\sigma(R O A)}$

where $R O A$ is the return on assets, $E A$ is the ratio of equity to total assets, and $\sigma(R O A)$ is the standard deviation of $R O A$ over a rolling window of 4-year period. As $Z$-score is an 
inverse proxy of the bank's total risk-taking or risk of default e.g. the smaller the $z$-score, the higher insolvency risk, we denote the risk-taking proxy (RISK) as the negative of $z$-score, i.e. $R I S K=-(z-$ score $)$, the higher the $z$-score, the lower the RISK and lower risk-taking.

To control for the risk arising from borrowers' weakened balance sheet (Bernanke et al, 1999), we follow Altunbas et al. (2010) and include the variable STOCK which is Shanghai Stock Exchange Composite Index to capture industry risk. Prior studies also suggest that general economic conditions and future expectations of economic activity may affect banks' risk-taking. Following Altunbas et al. (2010), we control for this effect by including real GDP growth rate one-year ahead, denoted by $Y$.

To obtain the involuntary excess reserve index (IER), the involuntary excess reserves ratio (IERR) is normalised using both the mean of the corresponding year and the mean of the sample as indicated in the formula 14 . We denote IER1 and IER2 as involuntary excess reserves obtained from the normalization process with involuntary excess reserve ratios IERR1 and IERR2, respectively. To control for the bank lending channel (see Bernanke and Blinder, 1988; Gambacorta, 2005), we include bank-specific characteristics i.e. liquidity $(L I Q)$, bank size $(S I Z E)$ and capitalisation $(C A P)$ which are defined in line with the study of Gambacorta (2005) as below:

$$
\begin{aligned}
& S I Z E_{i t}=\log A_{i t}-\frac{\sum_{i=1}^{N} \log A_{i t}}{N_{t}} \\
& L I Q_{i t}=\frac{L_{i t}}{A_{i t}}-\left(\sum_{t=1}^{T} \frac{\sum_{i=1}^{N} L_{i t} / A_{i t}}{N_{t}}\right) / T \\
& C A P_{i t}=\frac{C_{i t}}{A_{i t}}-\left(\sum_{t=1}^{T} \frac{\sum_{i=1}^{N} C_{i t} / A_{i t}}{N_{t}}\right) / T
\end{aligned}
$$


$I E R_{i t}=I E R R_{i t}-\left(\sum_{t=1}^{T} \frac{\sum_{i=1}^{N} I E R R_{i t}}{N_{t}}\right) / T$

where $N$ and $T$ are number of observations and number of years, respectively. Moreover, $L$ denotes liquid assets as defined by BankScope, which includes cash, government bonds, short-term claims on other banks (including certificates of deposit), and, where appropriate the trading portfolio. $C$ and $A$ refer to equity (capital) and total assets, respectively.

Table 1 provides the summary statistics for the variables. Taylor 1 and Taylor 2 are obtained from the residuals of Taylor rule estimations, and they are normally distributed and have zero-mean property. Taylor 1 varies between $-0.7 \%$ and $0.7 \%$, Taylor2 fluctuates between $0.3 \%$ and $0.4 \%$. Both Taylor 1 and Taylor 2 are positive in $50 \%$ of number of observations. IER 1 and IER2 have the means of zero. IER1 ranges from $-22 \%$ to $0.33 \%$ of deposits and is positive in $44 \%$ of number of observations. IER2 deviates from $-12 \%$ to $32 \%$ of deposits and is also positive in $44 \%$ of number of observations. $z$-score has the mean of 36.15 and ranges from 1.23 to 99.4 , and reflectively $R I S K$ varies between -99.4 and -1.23 with the mean of 36.15. Table 2 provides the unit-root tests results for the variables. The Augmented DickeyFuller and Phillips-Perron unit-root tests results indicate that all the variables are stationary.

(Insert Tables $1 \& 2$ here please)

Table 1 Summary Statistics for Risk-taking Estimations

\begin{tabular}{|l|l|l|l|l|l|l|l|}
\hline $\begin{array}{l}\text { Variabl } \\
\text { e }\end{array}$ & Mean & $\begin{array}{l}\text { Std. } \\
\text { Dev. }\end{array}$ & $\begin{array}{l}\text { Skewnes } \\
\text { s }\end{array}$ & $\begin{array}{l}\text { Kurtosi } \\
\text { s }\end{array}$ & Min & Max & $\begin{array}{l}\text { Jarqu } \\
\text { e-Bera }\end{array}$ \\
\hline Taylor1 & 0 & 0.003 & 0.201 & 1.46 & -0.007 & 0.007 & 0.4 \\
\hline Taylor2 & 0 & 0.002 & -0.105 & -1.617 & -0.003 & 0.004 & 1.54 \\
\hline Z-SCore & 36.152 & 22.187 & 0.906 & 0.144 & 1.23 & 99.4 & $47.82^{*}$ \\
\hline RISK & - & 22.187 & -0.906 & 0.144 & -99.4 & -1.23 & $47.82^{*}$ \\
\hline STOCK & 2290.1 & 946.04 & 0.694 & -0.535 & 1153.5 & 4237. & $71^{*}$ \\
\hline
\end{tabular}




\begin{tabular}{|c|c|c|c|c|c|c|c|}
\hline & & & & & 5 & 7 & \\
\hline$Y$ & 0.099 & 0.010 & -0.136 & -0.494 & 0.071 & 0.114 & $10.44 *$ \\
\hline IER1 & 0 & 0.046 & 1.35 & 11.712 & -0.219 & 0.328 & $2651 *$ \\
\hline IER2 & 0 & 0.041 & 2.227 & 15.05 & -0.12 & 0.32 & $2576^{*}$ \\
\hline$L I Q$ & 0.004 & 0.132 & 1.759 & 4.508 & -0.213 & 0.635 & $654.2 *$ \\
\hline$C A P$ & 0.001 & 0.12 & 3.489 & 13.948 & -0.229 & 0.78 & $4893^{*}$ \\
\hline$S I Z E$ & 0 & 2.058 & 0.522 & 0.006 & -4.724 & 5.202 & $26.53 *$ \\
\hline
\end{tabular}

Note: $*$ denotes the rejection of normal distribution at the $1 \%$ significance level.

Table 2 Unit Root Tests for Risk-taking Estimations Variables

\begin{tabular}{|l|l|l|}
\hline Variable & $\begin{array}{l}\text { Augmented Dickey- } \\
\text { Fuller }\end{array}$ & Phillips-Perron \\
\hline Taylor1 & $-8.044^{*}$ & $-9.725^{*}$ \\
\hline Taylor2 & $-6.531^{*}$ & $-6.713^{*}$ \\
\hline z-SCore & $163.0117^{*}$ & $163.0117^{*}$ \\
\hline RISK & $163.0117^{*}$ & $163.0117^{*}$ \\
\hline STOCK & $819.1679^{*}$ & $819.1679^{*}$ \\
\hline Y & $644.8130^{*}$ & $334.8188^{*}$ \\
\hline IER1 & $575.7617^{*}$ & $575.7617^{*}$ \\
\hline IER2 & $225.648^{*}$ & $225.648^{*}$ \\
\hline LIQ & $311.8068^{*}$ & $311.8068^{*}$ \\
\hline CAP & $244.7292^{*}$ & $244.7292^{*}$ \\
\hline SIZE & $252.3623^{*}$ & $262.1405^{*}$ \\
\hline NOte: & & \\
\hline
\end{tabular}

Note: * denotes the rejection of the unit root hypothesis at the $1 \%$ significance level. 


\subsection{Econometric Model}

\subsubsection{System Generalised Method of Moments (SGMM) Model}

Following the studies of Altunbas et al. (2010), Tabak et al. (2010), and Delis and Kouretas (2011), the risk-taking is estimated by the following dynamic model:

$$
\begin{aligned}
\text { RISK }_{i t} & =\alpha_{i}+\beta_{1} \text { RISK }_{i, t-1}+\beta_{2} \text { LIQ }_{i, t-1}+\beta_{3} \text { SIZE }_{i, t-1}+\beta_{4} \text { CAP }_{i, t-1}+\beta_{5} \text { IER }_{i, t-1}+\beta_{6} \text { Taylor }_{t-1} \\
& +\beta_{7} \text { IER }_{i, t-1} \times \text { Taylor }_{t-1}+\beta_{8} \text { STOCK }_{t-1}+\beta_{9} Y_{t+1}+\beta_{10} \text { OWNERSHIP }_{i t}+\beta_{11} \text { YEAR }_{t}+\varepsilon_{i t}
\end{aligned}
$$

where $\alpha_{i}$ is a constant term, $\varepsilon_{i t}$ is a well-behaved error term. RISK is measured as the negative of $z$-score. The interaction term IER $\times$ Taylor captures the impact of involuntary excess reserves on risk-taking in response to the monetary policy regime change. The Chinese monetary policy is argued to be more enforceable to Chinese state-owned banks compared to non-state-owned banks (Geiger, 2008). Prior studies also point out that foreign banks can seek for fund support from home banks and become less affected by monetary policy shock (Tabak et al., 2010; Ahtik, 2012). We control for ownership effect by including OWNERSHIP dummy which has the value of 1 for state-owned banks, 2 for non-state-owned banks and 3 for foreign banks. YEAR is a time dummy variable.

Taking into account the relatively small sample period, only the first lag of dependent variable is considered, and this is in line with prior studies (see Altunbas et al., 2010; Tabak et al., 2010). 'System' GMM (SGMM) estimator is use to estimate the model because ordinary least squares estimator (OLS) is biased in dynamic models. SGMM developed by Arellano and Bond's (1991) and further advanced by Arellano and Bover (1995) and Blundell and Bond (1998) provides consistent estimation in dynamic model with lags of dependent variable. Moreover, SGMM is efficient on unbalanced panel with high N/T ratio (where $\mathrm{N}$ is number of groups and $\mathrm{T}$ is time periods) (Arellano and Bond, 1991; Roodman, 2006). In addition, SGMM also allow for fixed effect in the panel (Arellano and Bover, 1995). SGMM is implemented by command xtabond2 on STATA package. Taylor-gap 
(Taylor) is considered as an endogenous variable. The interaction term, ownership and time dummies are treated as strictly exogenous variables, the others are treated as predetermined variables. The optimal model is selected based on the criteria suggested by (Arellano and Bond, 1991) and Roodman (2006, 2009) in Appendix 1.

\subsubsection{Monetary Policy Dummy Model}

Altunbas et al. (2010), Gaggl and Valderrama (2010), Maddaloni and Peydró (2011) and Michalak (2012) point out that the positive Taylor-gap indicates the tightening monetary policy regime and the negative Taylor-gap indicates the expansionary monetary policy regime. We further study the effect of the tightening monetary policy regime on risk-taking behaviour by examining the monetary policy dummy instead of the level of Taylor-gap as in the SGMM model. The monetary policy dummy model is presented as follows:

$$
\begin{aligned}
\text { RISK }_{i t} & =\alpha_{i}+\beta_{1} \text { RISK }_{i, t-1}+\beta_{2} \text { LIQ }_{i, t-1}+\beta_{3} \text { SIZE }_{i, t-1}+\beta_{4} \text { CAP }_{i, t-1}+\beta_{5} \text { IER }_{i, t-1}+\beta_{6} \text { DTaylor }_{t-1} \\
& +\beta_{7} \text { DIER }_{i, t-1} \times \text { DTaylor }_{t-1}+\beta_{8} \text { STOCK }_{t-1}+\beta_{9} Y_{t+1}+\beta_{10} \text { OWNERSHIP }_{i t}+\beta_{11} \text { YEAR }_{t}+\varepsilon_{i t}
\end{aligned}
$$

where DTaylor and DIER are monetary policy dummy and involuntary excess reserves dummy variables, respectively. The monetary policy dummy has the value of 1 if the monetary policy index is positive (Taylor $>0$ ), indicating the tightening monetary policy regime. The monetary policy dummy has the value of 0 if the monetary policy index is nonpositive (Taylor $\leq 0$ ), indicating the expansionary monetary policy regime. The involuntary excess reserve dummy has the value of 1 for the positive involuntary excess reserve (IER > $0)$, and 0 for non-positive involuntary excess reserve $(I E R \leq 0)$. The involuntary excess reserve dummy value of 1 indicates that banks hold unwanted reserves and are willing to take aggressive lending. The interaction between the monetary policy dummy and the involuntary excess reserve dummy gives the value of 1 for the case of positive involuntary excess reserve in the tightening monetary policy regime. Similarly, the interaction has the value of 0 for the cases with expansionary monetary policy regime (for both positive and negative involuntary 
excess reserve), and with negative involuntary excess reserve (for both tightening and expansionary monetary policy regimes). The values of the interaction term are illustrated in Figure 1. The interaction between monetary policy dummy and involuntary excess reserve dummy reflects the effect of tightening policy regime on the risk-taking behaviour of banks that have positive involuntary excess reserves. The model is estimated by SGMM estimator because OLS is biased in dynamic model.

(Insert Figure 1 here please)

\section{Figure1: The Interaction between Monetary Policy Dummy (DTaylor) and Involuntary Excess reserves Dummy (DIER)}

Tightening monetary policy (1)

\begin{tabular}{|c|c|c|c|c|}
\hline $\begin{array}{l}\text { Non-positive } \\
\text { involuntary } \\
\text { reserves }(0)\end{array}$ & excess & 0 & 1 & $\begin{array}{l}\text { Positive involuntary } \\
\text { excess reserves (1) }\end{array}$ \\
\hline & & 0 & 0 & \\
\hline
\end{tabular}

\section{$4 \quad$ Results and Discussion}

\subsection{Main Estimations Results and Discussion}

The two models are estimated by two alternative measures of involuntary excess reserves (i.e. IER 1 and IER2) and two alternative monetary policy indexes (i.e. Taylor 1 and Taylor 2 ). The estimations residuals are free of unit root and serial correlation. The results for SGMM and Monetary Policy Dummy estimations are reported in Tables 3 and 4 respectively. The three bank-specific characteristics - LIQ, SIZE and CAP do not show any significant impacts on risk taking. Banks tend to take greater risk at higher stock index STOCK. Similarly, the expectation of higher future economic growth $(Y)$ tends to induce banks to take greater risk. 
The involuntary excess reserves (IER) have a positive relationship with risk taking $(R I S K)$ as expected, supporting the hypothesis H1. The positive relationship is slightly significant for the SGMM estimations but becomes more significant in the Monetary Policy Dummy estimations. This result indicates that, banks with larger involuntary excess reserves tend to take greater risk. This evidence is in line with the theory that excess liquidity impact on the bank risk taking behaviour (Acharya and Naqvi, 2012). The positive relationship between involuntary excess reserves and risk taking may be resulted from the volume-based compensation policy in Chinese banks. In the presence of involuntary excess reserves, the illiquidity risk is considered to be low and bank managers appear to lend out aggressively to increase credit volume and compensation. Under the volume-based compensation policy, the liquidity surplus may induce the bank managers to aggressively lend out by relaxing lending standards, and therefore the banks take in greater risk (Acharya and Naqvi, 2012).

The impact of the monetary policy stance on risk taking is shown as follows:

$$
\frac{\partial R I S K}{\partial \text { Taylor }}=\beta_{6}+\beta_{7} \times I E R
$$

When $I E R$ is zero, the impact of monetary policy stance on risk taking is shown as $\frac{\partial R I S K}{\partial \text { Taylor }}=\beta_{6}$. As the negative $\beta_{6}$ is not significant, monetary policy stance (Taylor) indicates insignificant negative impact on risk taking for both Taylor 1 and Taylor 2 estimations, failing to support the second hypothesis $(\mathrm{H} 2)$. When IER increases, the tightening of monetary policy tends to reduce risk taking as $\beta_{7}$ is negative and significant. Similarly, the monetary policy dummy, (DTaylor), exerts no significant effect on bank risk taking behaviour. The results indicate that there is no significant difference on banks' risk taking behaviour between tightening and expansionary monetary policy regimes. These findings contradict the evidence documented by Jimenez et al. (2009) and Ioannidou et al. (2009) who find that expansionary monetary policy induces banks to take in greater risk. 
In the SGMM model, the interaction between involuntary excess reserves and monetary policy (IER $\times$ Taylor) is found to be negative to the risk taking although only significant in estimations 1 and 3. Similarly, in the Monetary Policy Dummy model, the interaction between monetary policy dummy and involuntary excess reserve dummy (DIER $\times$ DTaylor) also has the negative relationship with risk taking, and this relationship is significant across all the estimations, supporting hypothesis 3 . These results indicate that banks with larger involuntary excess reserves tend to reduce risk taking more rapidly in response to the tightening monetary policy. This is in line with the studies of Jimenez et al. (2009) and Ioannidou et al. (2009), although these prior studies focus on the impact of monetary policy on risk taking of liquid banks rather than banks with involuntary excess reserves. In short, although the tightening monetary policy does not appear to reduce risk taking behaviour of Chinese banks $(\mathrm{H} 2)$, it tends to hold back the risk taking behaviour induced by involuntary excess reserves (H3). This finding is consistent with Rajan's (2006) argument that tightening monetary policy can materialise tail risk. When the tail risk is materialised and becomes no longer easy to be concealed, the risk taking incentive of involuntary excess reserves is restrained. Therefore, the tightening monetary policy tends to reduce the risk taking incentive of involuntary excess reserves.

(Insert Tables $3 \& 4$ here please) 
Table 3: Impact of Monetary Policy and Involuntary Excess Reserves on Risk-taking - SGMM Estimations

\begin{tabular}{|c|c|c|c|c|}
\hline \multirow{2}{*}{$\begin{array}{l}\text { Dependent Variable: } \\
{[R I S K=-(z-s c o r e)]}\end{array}$} & \multicolumn{2}{|c|}{ Taylor1 } & \multicolumn{2}{|c|}{ Taylor2 } \\
\hline & $\begin{array}{c}\text { IER1 } \\
(1)\end{array}$ & $\begin{array}{c}\text { IER2 } \\
(2) \\
\end{array}$ & $\begin{array}{c}\text { IER1 } \\
(3)\end{array}$ & $\begin{array}{c}\text { IER2 } \\
(4) \\
\end{array}$ \\
\hline Constant & $\begin{array}{l}-122.12 * * * \\
(45.98)\end{array}$ & $\begin{array}{l}- \\
119.94 * * * \\
(36.08)\end{array}$ & $\begin{array}{l}-126.66^{* *} \\
(48.66)\end{array}$ & $\begin{array}{l}- \\
117.31 * * * \\
(38.04)\end{array}$ \\
\hline RISK (lag1) & $\begin{array}{l}0.12 \\
(0.22)\end{array}$ & $\begin{array}{l}0.13 \\
(0.15)\end{array}$ & $\begin{array}{l}0.13 \\
(0.23)\end{array}$ & $\begin{array}{l}0.13 \\
(0.16)\end{array}$ \\
\hline$L I Q$ & $\begin{array}{l}39.58 \\
(31.27)\end{array}$ & $\begin{array}{l}8.79 \\
(41.96)\end{array}$ & $\begin{array}{l}54.12 \\
(36.58)\end{array}$ & $\begin{array}{l}11.36 \\
(40.91)\end{array}$ \\
\hline$S I Z E$ & $\begin{array}{l}-10.8^{*} \\
(6.17)\end{array}$ & $\begin{array}{l}-5.74 \\
(3.87)\end{array}$ & $\begin{array}{l}-12.41 * \\
(7.22)\end{array}$ & $\begin{array}{l}-8.09 * \\
(4.73)\end{array}$ \\
\hline CAP & $\begin{array}{l}-180.68 \\
(117.33)\end{array}$ & $\begin{array}{l}-94.7 \\
(70.7)\end{array}$ & $\begin{array}{l}-224.4^{*} \\
(130.76)\end{array}$ & $\begin{array}{l}-121.45 \\
(82.38)\end{array}$ \\
\hline IER & $\begin{array}{l}162.02 * \\
(89.17)\end{array}$ & $\begin{array}{l}127.51 * \\
(76.97)\end{array}$ & $\begin{array}{l}196.24 * * \\
(99.94)\end{array}$ & $\begin{array}{l}145.27 * \\
(86.23)\end{array}$ \\
\hline Taylor & $\begin{array}{l}-903.86 \\
(1028.78)\end{array}$ & $\begin{array}{l}-1170.11 \\
(863.34)\end{array}$ & $\begin{array}{l}-793.97 \\
(1146.51)\end{array}$ & $\begin{array}{l}-1148.19 \\
(950.34)\end{array}$ \\
\hline IER $\times$ Taylor & $\begin{array}{l}- \\
42196.78 * * \\
(21555.38)\end{array}$ & $\begin{array}{l}-26477.03 \\
(19416.9)\end{array}$ & $\begin{array}{l}\text { - } \\
42495.21 * \\
(23139.24)\end{array}$ & $\begin{array}{l}-24971.91 \\
(18991.82)\end{array}$ \\
\hline STOCK & $\begin{array}{l}0.02 * * * \\
(0.004)\end{array}$ & $\begin{array}{l}0.02 * * * \\
(0.003)\end{array}$ & $\begin{array}{l}0.02 * * * \\
(0.004)\end{array}$ & $\begin{array}{l}0.02 * * * \\
(0.004)\end{array}$ \\
\hline$Y$ & $\begin{array}{l}616.51 * \\
(338.78)\end{array}$ & $\begin{array}{l}482.25 * * \\
(204.26)\end{array}$ & $\begin{array}{l}674.67 * \\
(376.18)\end{array}$ & $\begin{array}{l}498.46^{* *} \\
(227.55)\end{array}$ \\
\hline $\begin{array}{ll}\text { Number } & \text { of } \\
\text { observations } & \end{array}$ & 228 & 200 & 228 & 200 \\
\hline Number of groups & 70 & 63 & 70 & 63 \\
\hline $\begin{array}{ll}\text { Number } & \text { of } \\
\text { instruments } & \end{array}$ & 36 & 56 & 36 & 56 \\
\hline Hansen p-value & 0.987 & 0.832 & 0.983 & 0.842 \\
\hline
\end{tabular}

Note: $1 . * * *, * *$ and $*$ denote statistical significance at the $1 \%, 5 \%$ and $10 \%$ significance levels, respectively.

2. Robust standard errors are reported in parentheses. 
Table 4: Impact of Monetary Policy and Involuntary Excess Reserves on Risk-taking - Monetary Policy Dummy Estimations

\begin{tabular}{|c|c|c|c|c|}
\hline \multirow{2}{*}{$\begin{array}{l}\text { Dependent } \\
\text { Variable: } \\
\text { [RISK=-(z-score })]\end{array}$} & \multicolumn{2}{|c|}{ Taylor1 } & \multicolumn{2}{|c|}{ Taylor 2} \\
\hline & $\begin{array}{c}\text { IER1 } \\
(5)\end{array}$ & $\begin{array}{c}\text { IER2 } \\
(6)\end{array}$ & $\begin{array}{c}\text { IER1 } \\
(7)\end{array}$ & $\begin{array}{c}\text { IER2 } \\
(8)\end{array}$ \\
\hline Constant & $\begin{array}{l}-106.66 * * \\
(51.64)\end{array}$ & $\begin{array}{l}-126.22 * * \\
(50.19)\end{array}$ & $\begin{array}{l}-72.96 \\
(70.04)\end{array}$ & $\begin{array}{l}-130.94 * * \\
(49.65)\end{array}$ \\
\hline RISK (lag1) & $\begin{array}{l}0.13 \\
(0.25)\end{array}$ & $\begin{array}{l}0.03 \\
(0.24)\end{array}$ & $\begin{array}{l}0.35 \\
(0.39)\end{array}$ & $\begin{array}{l}0.004 \\
(0.24)\end{array}$ \\
\hline$L I Q$ & $\begin{array}{l}32.29 \\
(34.15)\end{array}$ & $\begin{array}{l}45.16 \\
(54.32)\end{array}$ & $\begin{array}{l}6.45 \\
(52.71)\end{array}$ & $\begin{array}{l}37.28 \\
(53.14)\end{array}$ \\
\hline SIZE & $\begin{array}{l}-13.16^{*} \\
(7.74)\end{array}$ & $\begin{array}{l}-11.23^{*} \\
(6.25)\end{array}$ & $\begin{array}{l}-14.77 \\
(9.31)\end{array}$ & $\begin{array}{l}-10.78 \\
(6.59)\end{array}$ \\
\hline$C A P$ & $\begin{array}{l}-184.22 \\
(141.12)\end{array}$ & $\begin{array}{l}-162.85^{*} \\
(95.81)\end{array}$ & $\begin{array}{l}-191.46 \\
(176.34)\end{array}$ & $\begin{array}{l}-168.99 \\
(102.96)\end{array}$ \\
\hline IER & $\begin{array}{l}245.51^{* *} \\
(107.8)\end{array}$ & $\begin{array}{l}289.25^{* *} \\
(117.5)\end{array}$ & $\begin{array}{l}344.22 * * \\
(177.96)\end{array}$ & $\begin{array}{l}318.22 * * \\
(138.37)\end{array}$ \\
\hline DTaylor & $\begin{array}{l}3.83 \\
(5.93)\end{array}$ & $\begin{array}{l}3.48 \\
(5.49)\end{array}$ & $\begin{array}{l}4.98 \\
(7.22)\end{array}$ & $\begin{array}{l}4.31 \\
(5.73)\end{array}$ \\
\hline DIER $\times$ DTaylor & $\begin{array}{l}-10.83 * * \\
(8.6)\end{array}$ & $\begin{array}{l}-11.16^{* *} \\
(9)\end{array}$ & $\begin{array}{l}-15.79 * * \\
(12.07)\end{array}$ & $\begin{array}{l}-12.29 * * \\
(9.16)\end{array}$ \\
\hline STOCK & $\begin{array}{l}0.02 * * * \\
(0.004)\end{array}$ & $\begin{array}{l}0.02 * * * \\
(0.004)\end{array}$ & $\begin{array}{l}0.02 * * * \\
(0.005)\end{array}$ & $\begin{array}{l}0.02 * * * \\
(0.004)\end{array}$ \\
\hline$Y$ & $\begin{array}{l}606.8 \\
(377.28)\end{array}$ & $\begin{array}{l}706.1 * * \\
(323.58)\end{array}$ & $\begin{array}{l}439.72 \\
(423.87)\end{array}$ & $\begin{array}{l}721.36^{* *} \\
(328.03)\end{array}$ \\
\hline $\begin{array}{ll}\text { Number } & \text { of } \\
\text { observations } & \end{array}$ & 228 & 200 & 228 & 200 \\
\hline Number of groups & 70 & 63 & 70 & 63 \\
\hline $\begin{array}{ll}\text { Number } & \text { of } \\
\text { instruments }\end{array}$ & 36 & 36 & 30 & 36 \\
\hline Hansen p-value & 0.991 & 0.997 & 0.989 & 0.997 \\
\hline
\end{tabular}


Note: $1 . * * *, * *$ and $*$ denote statistical significance at the $1 \%, 5 \%$ and $10 \%$ significance levels, respectively.

2. Robust standard errors are reported in parentheses.

\subsection{Additional Analysis and Robustness Tests}

It is argued that, the PBC sets loan limits mainly to the four state-owned banks to moderate credit supply (Geiger, 2008), and the loan limits may restrain the risk taking behaviour of the state-owned banks. To overcome the loan limit effect and check the robustness of the study results, we exclude the four state-owned banks from the sample. The robust estimations show the similar results to the main estimations where the four state-owned banks are included.

Prior studies suggest that the change in Chinese accounting standards in 2008 may cause data inconsistency in financial statements reporting. To address this concern, Chow tests (see Chow, 1960) are employed to check for the model stability in two periods before and after 2008. The Chow tests results show that there is no significant difference in the estimated parameters between the two periods. We also control for the effect of mergers and acquisitions (M\&A) on financial statements reporting by including M\&A dummy, the results are identical to the main estimations that exclude M\&A dummy. Prior studies also suggest that city commercial banks and rural commercial banks tend to operate within a provincial scale rather than a national scale (Xu, 2011), we control this effect by using expected provincial GDP growth for city commercial banks and rural commercial banks while the expected national GDP growth is used for other banks. The robustness results are similar to the main estimations where the expected national GDP growth is used for all banks. Beside the monetary policy stance index (Taylor), we also control for the revaluation effect of monetary policy shock on risk-taking (see Adrian and Shin, 2009, 2010) by incorporating the change in one-year deposit benchmark rate and the change in the reserve requirement ratio which is used as a primary tool to sterilise excess liquidity in the banking system (Anderson, 2009). We denote $I P$ (interest rate policy) and $R R R$ as the change in deposit benchmark rate 
and the change in reserve requirement ratio, respectively. The robustness results show that the effects of involuntary excess reserves and monetary policy stance on risk-taking are similar to the main estimations where monetary policy interest rates and reserve requirement ratio are not included. We also examine the difference in risk-taking behaviour of banks that have and lack involuntary excess reserves. In the Monetary Policy Dummy model, we replace the level of involuntary excess reserves (IER) with involuntary excess reserve dummy variable $(D I E R)$. The results show that banks with positive involuntary excess reserves tend to take greater risk compared to banks with negative involuntary excess reserves. Banks with positive involuntary excess reserves also tend to reduce risk-taking more rapidly in response to the tightening monetary policy. This is consistent with the main findings and supports the hypotheses $\mathrm{H} 1$ and $\mathrm{H} 3$. The summary of the robustness tests is presented in Table 5. The results of additional analysis and robustness tests are not reported but available upon request.

\section{$5 \quad$ Summary and Policy Implications}

This study examines the effects of involuntary excess reserves and monetary policy stance on risk-taking behaviour of Chinese banks. The study finds that banks with large involuntary excess reserves tend to take greater risk. Tightening monetary policy does not appear to significantly reduce risk-taking behaviour. However, during the tightening monetary policy regime, banks with larger involuntary excess reserves tend to reduce risk-taking more rapidly. This evidence implies that tightening monetary policy can materialise the tail risk and make the tail risk no longer easy to be concealed, and therefore, the risk-taking incentive of the involuntary excess reserve is restrained.

Since 2003, the PBC has been using reserve requirement as a primary tool to reduce excess liquidity in the banking system (Anderson, 2009), the finding of this study suggests that the PBC can also increase the policy benchmark rate to reduce the risk-taking behaviour driven by involuntary excess reserves. Although the evidence documented in this study appears 
significant and contributes to under-researched topic, the sample size appears to be the limitation of the study. Further studies appear warranted if quarterly data becomes available to better capture the impact of monetary policy on risk-taking under in the text of large involuntary excess reserves in the Chinese banking system.

Table 5 Additional Analysis and Robustness Tests for Risk-taking Estimations

\begin{tabular}{|c|c|c|c|}
\hline Issue & Test performed & Specification & Finding \\
\hline $\begin{array}{l}\text { Loan ceilings set for } \\
\text { four state-owned } \\
\text { banks }\end{array}$ & $\begin{array}{l}\text { SGMM and } \\
\text { Monetary Policy } \\
\text { Dummy models } \\
\text { estimations for the } \\
\text { sample which } \\
\text { excludes the four } \\
\text { state-owned banks. }\end{array}$ & $\begin{array}{l}\text { The four state-owned banks } \\
\text { are excluded from the } \\
\text { sample. }\end{array}$ & $\begin{array}{l}\text { No significant difference } \\
\text { in the results compared } \\
\text { with estimations which } \\
\text { include the four state- } \\
\text { owned commercial banks } \\
\text { in the sample. }\end{array}$ \\
\hline $\begin{array}{l}\text { Data consistency: } \\
\text { Chinese Accounting } \\
\text { Standards Changes } \\
\text { in } 2008\end{array}$ & $\begin{array}{l}\text { Chow tests for } \\
\text { SGMM and } \\
\text { Monetary Policy } \\
\text { Dummy models }\end{array}$ & $\begin{array}{l}\text { Chow test for periods before } \\
\text { and after } 2008\end{array}$ & $\begin{array}{l}\text { No significant difference } \\
\text { in the parameters between } \\
\text { the } 2 \text { periods }\end{array}$ \\
\hline $\begin{array}{l}\text { Merger and } \\
\text { Acquisition (M\&A) }\end{array}$ & $\begin{array}{lr}\text { SGMM } & \text { and } \\
\text { Monetary } & \text { Policy } \\
\text { Dummy } \quad \text { models } & \\
\text { controlled for } & \text { M\&A }\end{array}$ & $\begin{array}{l}\text { Include M\&A dummies } \\
\text { with value of } 1 \text { for merger } \\
\text { and acquisition event and } 0 \\
\text { otherwise }\end{array}$ & $\begin{array}{l}\text { No significant difference } \\
\text { in the results compared } \\
\text { with main estimations } \\
\text { which do not include } \\
\text { M\&A dummy. }\end{array}$ \\
\hline Provincial operation & $\begin{array}{lr}\text { SGMM } & \text { and } \\
\text { Monetary } & \text { Policy } \\
\text { Dummy } & \text { models } \\
\text { with } & \text { expected } \\
\text { provincial } & \text { GDP } \\
\text { growth rate } & \end{array}$ & $\begin{array}{l}\text { Expected national real GDP } \\
\text { growth rate is applied for } \\
\text { State-owned commercial } \\
\text { banks, joint stock } \\
\text { commercial banks and } \\
\text { foreign banks. Expected } \\
\text { provincial real GDP growth } \\
\text { rate is applied for city } \\
\text { commercial banks and rural } \\
\text { commercial banks. }\end{array}$ & $\begin{array}{l}\text { No significant difference } \\
\text { in the results compared } \\
\text { with estimations where } \\
\text { expected national GDP } \\
\text { growth rate is used for all } \\
\text { banks. }\end{array}$ \\
\hline $\begin{array}{l}\text { Revaluation effect of } \\
\text { policy interest rate } \\
\text { and reserve } \\
\text { requirement shocks }\end{array}$ & $\begin{array}{lr}\text { SGMM } & \text { and } \\
\text { Monetary } & \text { Policy } \\
\text { Dummy models } & \text { molicy }\end{array}$ & $\begin{array}{l}\text { Include the change in } \\
\text { deposit benchmark rate and } \\
\text { reserve requirement ratio } \\
\text { into the SGMM estimations. }\end{array}$ & $\begin{array}{l}\text { No significant difference } \\
\text { in the results compared } \\
\text { with estimations which do } \\
\text { not include policy interest }\end{array}$ \\
\hline
\end{tabular}




\begin{tabular}{|c|c|c|c|}
\hline & $\begin{array}{l}\text { interest rate and } \\
\text { reserve requirement } \\
\text { shocks }\end{array}$ & & $\begin{array}{l}\text { rate and reserve } \\
\text { requirement shocks. }\end{array}$ \\
\hline $\begin{array}{l}\text { Different risk-taking } \\
\text { behaviours between } \\
\text { banks with positive } \\
\text { IER against banks } \\
\text { with negative IER }\end{array}$ & $\begin{array}{lr}\text { Monetary } & \text { Policy } \\
\text { Dummy } & \text { model } \\
\text { estimations } & \text { with } \\
\text { DIER } & \end{array}$ & $\begin{array}{l}\text { In the dummy model, } \\
\text { replace IER by IER dummy } \\
\text { (DIER) }\end{array}$ & $\begin{array}{l}\text { Banks with positive IER } \\
\text { tend to take greater risk } \\
\text { and reduce risk-taking } \\
\text { more rapidly compared to } \\
\text { banks with negative IER. }\end{array}$ \\
\hline
\end{tabular}




\section{References}

Acharya, V., and Naqvi, H. (2012). The Seeds of a Crisis: A Theory of Bank Liquidity and Risk-Taking over the Business Cycle. Journal of Financial Economics, 106(2), 349-366.

Adrian, T., and Shin, H. S. (2009). Money, Liquidity and Monetary Policy. American Economic Review, 99(2), 600-605.

Adrian, T., and Shin, H. S. (2010). Financial intermediaries and monetary economics. Handbook of Monetary Economics, 3(A), 601-650.

Agenor, P.-R., Aizenman, J., and Hoffmaister, A. W. (2004). The credit crunch in East Asia: what can bank excess liquid assets tell us? Journal of International Money and Finance, 23(1), 27-49.

Ahtik, M. (2012). Bank Lending Channel in Slovenia: Panel Data Analysis. Prague Economic Papers, 1, 50-68.

Aikaeli, J. (2011). Determinants of Excess Liquidity in Tanzanian Commercial Banks. African Finance Journal, 13(1), 47-63.

Allen, F., Qian, J. "QJ," Zhang, C., and Zhao, M. (2011). China's financial system: opportunities and challenges. In: Fan, J. and Morck, R. (Eds), Capitalizing China, University of Chicago Press, forthcoming.

Altunbas, Y., Gambacorta, L., and Marques-Ibanez, D. (2010). Does monetary policy affect bank risk-taking? ECB Working Paper No. 1166.

Anderson, J. (2009). The China monetary policy handbook. In: Barth, J.R., Tatom,J.A. and Yago,G. (Eds.), China's emerging financial markets - Challenges and opportunities, Milken Institute, CA, USA.

Angeloni, I., and Faia, E. (2009). A Tale of Two Policies: Prudential Regulation and Monetary Policy with Fragile Banks. Kiel Working Paper No. 1569.

Angeloni, I., Faia, E., and Lo Duca, M. (2010). Monetary policy and risk taking. University of Frankfurt, Mimeo.

Arellano, M., and Bond, S. (1991). Some tests of specification for panel data: Monte Carlo evidence and an application to employment equations. Review of Economic Studies, 58(2), 277-297.

Arellano, M., and Bover, O. (1995). Another look at the instrumental variables estimation of errorcomponents models. Journal of Econometrics, 68(1), 29-51.

Baxter, M., and King, R. G. (1999). Measuring Business Cycles: Approximate Band-Pass Filters for Economic Time Series. Review of Economics and Statistics, 81, 575-593. 
Berger, A., Klapper, L., and Turk-Ariss, R. (2009). Bank Competition and Financial Stability. Journal of Financial Services Research, 35(2), 99-118.

Bernanke, B. S., and Blinder, A. S. (1988). Credit, money, and aggregate demand. American Economic Review, 78(2), 435-439.

Bernanke, B. S., Gertler, M., and Gilchrist, S. (1999). The financial accelerator in a quantitative business cycle framework. In: Taylor, J. and Woodford, (Eds), Handbook of Macroeconomics, Amsterdam, pp 1341-393.

Bindseil, U., Camba-Mendez, G., Hirsch, A., and Weller, B. (2006). Excess reserves and the implementation of monetary policy of the ECB. Journal of Policy Modeling, 28(5), 491-510.

Blundell, R., and Bond, S. (1998). Initial conditions and moment restrictions in dynamic panel data models. Journal of Econometrics, 87, 115-143.

Borio, C., and Zhu, H. (2008). Capital regulation, risk-taking and monetary policy: a missing link in the transmission mechanism? BIS Working Papers, No. 268.

Boyd, J, Graham, G., and Hewitt, R. (1993). Bank Holding Company Mergers with Nonbank Financial Firms. Journal of Banking and Finance, 17(1), 43-63.

Boyd, John, De Nicolo, G., and Jalal, M. (2006). Bank Risk-Taking and Competition Revisited: New Theory and New Evidence. IMF Working paper, WP/06/297.

Buch, C. M., Eickmeier, S., and Prieto, E. (2010). Macroeconomic factors and micro-level bank risk. CESifo Working Paper No. 3194.

Buch, C. M., Eickmeier, S., and Prieto, E. (2011). In search for yield? New survey-based evidence on bank risk taking. CESifo Working Paper No. 3375.

Chen, H., Chen, Q., and Gerlach, S. (2011). The implementation of monetary policy in China: The interbank market and bank lending. HKIMR Working Papers, No. 26.

Chow, G. C. (1960). Tests of Equality Between Sets of Coefficients in Two Linear Regressions. Econometrica, 28(3), 591-605.

De Graeve, F., Kick, T., and Koetter, M. (2008). Monetary policy and financial (in)stability: An integrated micro-macro approach. Journal of Financial Stability, 4(3), 205-231.

De Nicolò, G., Dell'Ariccia, G., Laeven, L., and Valencia, F. (2010). Monetary policy and bank risk taking. IMF Staff Position Note, SPN/10/09.

Delis, M. D., and Brissimis, S. N. (2010). Bank heterogeneity and monetary policy transmission. ECB Working Paper No. 1233.

Delis, M. D., and Kouretas, G. (2011). Interest rates and bank risk-taking. Journal of Banking and Finance, 35(4), 840-855. 
Delis, M., Hasan, I., and Mylonidis, N. (2011). The risk-taking channel of monetary policy in the USA: Evidence from micro-level data. MPRA Working Paper No. 34084.

Fan, L., Yu, Y., and Zhang, C. (2011). An empirical evaluation of China's monetary policies. Journal of Macroeconomics, 33(2), 358-371.

Gaggl, P., and Valderrama, M. T. (2010). Does a Low Interest Rate Environment Affect Risk Taking in Austria? Monetary Policy and the Economy, Q4/10(4), 32-48.

Gambacorta, L. (2005). Inside the bank lending channel. European Economic Review, 49(7), 1737-1759.

Gambacorta, L. (2009). Monetary policy and the risk-taking channel. BIS Quarterly Review, 2009(December), 43-53.

Geiger, M. (2008). Instruments of monetary policy in China and their effectiveness: 19942006. United Nations Conference on Trade and Development, No. 187.

Green, S., and Chang, J. (2006). On the Ground, Asia: The PBoC's Big Money Problem. Standard Chartered, June.

Guo, S., and Li, C. (2011). Excess liquidity, housing price booms and policy challenges in China. China and World Economy, 19(6), 76-91.

He, D., and Wang, H. (2012). Dual-track interest rates and the conduct of monetary policy in China. China Economic Review, 23(4), 928-947.

Hodrick, R., and Prescott, E. C. (1997). Postwar U.S. Business Cycles: An Empirical Investigation. Journal of Money, Credit and Banking, 29(1), 1-16.

Huang, Y., Wang, X., and Hua, X. (2010). What determine China's inflation? China Economic Journal, 3(1), 69-86.

Ioannidou, V., Ongena, S., and Peydro, J. L. (2009). Monetary policy, risk-taking and pricing: Evidence from a quasi-natural experiment. CentER Discussion Paper No. 2009-31S.

Jimenez, G., Ongena, S., Peydro, J. L., and Saurina, J. (2009). Hazardous times for monetary policy: what do twenty-three million bank loans say about the effects of monetary policy on credit risk? CEPR Discussion Paper No. 6514.

Kashyap, A. K., and Stein, J. C. (2000). What do a million observations on banks say about the transmission of monetary policy? American Economic Review, 90(3), 407-428.

Laurens, B. J., and Maino, R. (2009). Monetary policy implementation in China: past, present and prospects. In: Barth, J.R., Tatom,J.A. and Yago,G. (Eds.), China's emerging financial markets - Challenges and opportunities, Milken Institute, CA, USA.

Liu, M.-H., Margaritis, D., and Tourani-Rad, A. (2009). Monetary policy and interest rate rigidity in China. Applied Financial Economics, 19(8), 647-657. 
Ma, G., Yan, X., and Liu, X. (2011). China's evolving reserve requirements. BIS Working Papers, No. 360.

Maddaloni, A., and Peydró, J.-L. (2011). Bank Risk-taking, Securitization, Supervision, and Low Interest Rates: Evidence from the Euro-area and the U.S. Lending Standards. Review of Financial Studies, 24(6), 2121-2165.

Michalak, T. C. (2012). The nexus between monetary policy, banking market structure and bank risk taking. In M. Balling and D. T. Llewellyn (Eds.), New Paradigms in Monetary Theory and Policy? (pp. 187-232). The European Money and Finance Forum, SUERF Study 2012/1.

Mussa, A. S. (2010). Asymmetric Bank Risk Taking and Monetary Policy. Western Michigan University, Working Paper.

Naughton, B. (1998). China's financial reform: Achievements and challenges. BRIE Working Paper, No. 112.

Nguyen, V. H. T. and Boateng, A. (2013). The Impact of Excess Reserves beyond Precautionary Levels on Bank Lending Channels in China, Journal of International Financial Markets, Institutions and Money, 26(C), 358-377

Paligorova, T., and Santos, J. A. C. (2012). When Is It Less Costly for Risky Firms to Borrow? Evidence from the Bank Risk-Taking Channel of Monetary Policy. Bank of Canada Working Paper 2012-10.

Porter, N., and $\mathrm{Xu}, \mathrm{T}$. (2009). What drives China's interbank market? IMF Working Paper, $W P / 09 / 189$.

Qian, J. "QJ," Strahan, P. E., and Yang, Z. (2011). The impact of incentives and communication costs on information production: Evidence from bank lending. Working Paper. http://www.ccfr.org.cn/cicf2011/papers/20110623060915.pdf.

Rajan, R. (2006). Has Finance Made the World Riskier? European Financial Management, 12(4), 499-533.

Ravn, M. O., and Uhlig, H. (2002). On Adjusting the Hodrick-Prescott Filter for the Frequency of Observations. Review of Economics and Statistics, 84(2), 371-376.

Roodman, D. (2006). How To Do xtabond2: An Introduction to "Difference" and "System" GMM in Stata. Center for Global Development Working Paper No. 103.

Roodman, David. (2009). Practitioners' Corner - A Note on the Theme of Too Many Instruments. Oxford Bulletin of Economics and Statistics, 71(1), 135-158.

Tabak, B., Laizy, M., and Cajueiro, D. (2010). Financial Stability and Monetary Policy - The case of Brazil. Central Bank of Brazil, Working Paper Series No. 217.

Taylor, J. B. (1993). Discretion Versus Policy Rules in Practice. Carnegie-Rochester Conference Series on Public Policy, 39(1), 195-214. 
Wei, X., Pan, S., Yang, S., Zhang, M., and Chen, M. (2008). Liquidity management of the participants in Chinese Real Time Gross Settlement Systems. Available at SSRN: http://ssrn.com/abstract $=1097533$.

$\mathrm{Xu}, \mathrm{Y}$. (2011). Towards a more accurate measure of foreign bank entry and its impact on domestic banking performance: The case of China. Journal of Banking and Finance, 35(4), 886-901.

Yang, J. (2010). Expectation, excess liquidity and inflation dynamics in China. Frontiers of Economics in China, 5(3), 412-429.

Zhang, Chengsi. (2009). Excess Liquidity, Inflation and the Yuan Appreciation: What Can China Learn from Recent History? The World Economy, 32(7), 998-1018.

Zhang, Chengsi, and Pang, H. (2008). Excess liquidity and inflation dynamics in China: 1997-2007. China and World Economy, 16(4), 1-15.

Zhao, Q. (2012). World Bank lowers China GDP forecast. People's Daily Online. Retrieved from http://english.peopledaily.com.cn/90778/7826739.html. 


\section{Appendices}

\section{Appendix 1 xtabond2 Model Selection Criteria}

\begin{tabular}{|c|c|}
\hline Criteria & Requirements Description \\
\hline F-test & $\begin{array}{l}\text { Reject the null hypothesis that independent variables are jointly } \\
\text { equal to zero }\end{array}$ \\
\hline Arellano-Bond test & $\begin{array}{l}\text { First-order serial correlation but no second-order serial } \\
\text { correlation in the residuals (Arelano and Bond, 1991) }\end{array}$ \\
\hline Sargan Test & $\begin{array}{l}\text { Sargan statistic is biased in one-step estimator with 'Robust' } \\
\text { option (Roodman, 2006). Therefore, Sargan Test is not } \\
\text { considered. }\end{array}$ \\
\hline $\begin{array}{l}\text { Difference-in- } \\
\text { Hansen }\end{array}$ & $\begin{array}{l}\text { P value } \geq 0.25 \text { (Roodman, 2009) } \\
P \text { value of } 1 \text { is the sign of inappropriate model (Roodman, 2009) }\end{array}$ \\
\hline Steady state & $\begin{array}{l}\text { The estimated coefficient on the lagged dependent variable } \\
\text { should have a value less than (absolute) unity (Roodman, 2009) }\end{array}$ \\
\hline $\begin{array}{l}\text { Number } \\
\text { instruments }\end{array}$ & $\begin{array}{l}\text { The number of instruments should not exceed the number of } \\
\text { groups (i.e. number of banks) (Roodman, 2009) }\end{array}$ \\
\hline $\begin{array}{l}\text { Optimal } \\
\text { instruments }\end{array}$ & $\begin{array}{l}\text { Roodman (2006, 2009) suggests reporting how the optimal } \\
\text { number of instruments. The standard treatment on lag-limits is } \\
\text { used, such that lag-limits start from lag2 for endogenous variable } \\
\text { (and from lag1 for exogenous and predetermined) to the most } \\
\text { available lag. The 'collapse' option is used to keep the number of } \\
\text { instruments within Stata's size limit. A number of other } \\
\text { regressions are estimated by adjusting the upper and lower lag- } \\
\text { limits. The regression which satisfies all the criteria listed above } \\
\text { and has highest p-value of Hansen J test is selected as the optimal } \\
\text { regression. }\end{array}$ \\
\hline
\end{tabular}

Source: Roodman, 2006; Roodman, 2009; Arelano and Bond, 1991 